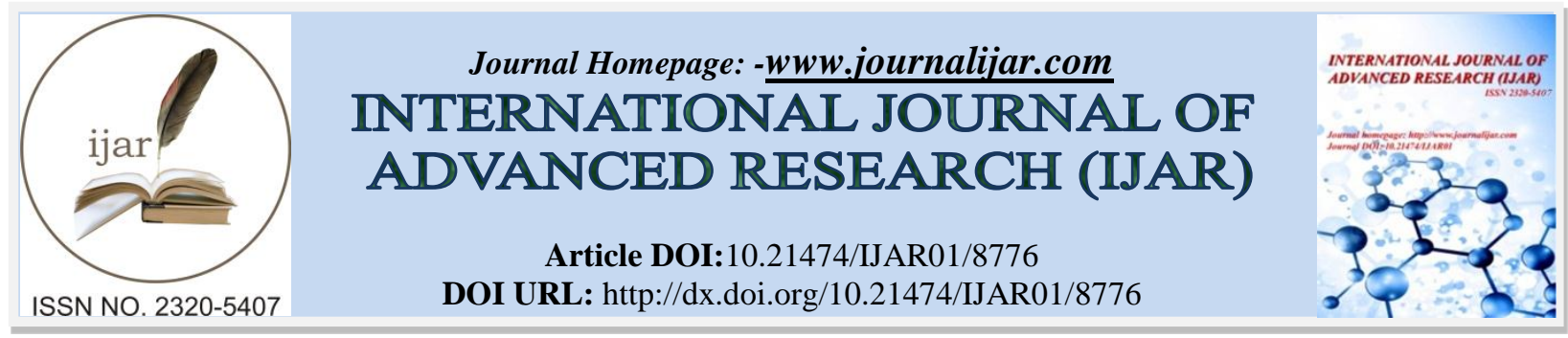

RESEARCH ARTICLE

\title{
ASSESSING THE DRUG SUPPLY AND DISTRIBUTION PROCESS OF MDA-LF PROGRAM OF LYMPHATIC FILARIASIS; POST 7 YEARS OF THE PROGRAM IMPLEMENTATION IN PEKALONGAN TOWN CENTRAL JAVA, INDONESIA.
}

Ali Jarghon, Hanifa Denny and Chriswardani Suryawati.

Faculty of Public Health, University of Diponegoro, Tembalang, Indonesia.

\section{Manuscript Info}

Manuscript History

Received: 20 January 2019

Final Accepted: 22 February 2019

Published: March 2019

\section{Key words:-}

Mass Drug Administration (MDA-LF),

Lymphatic Filariasis (LF), Coverage,

Compliance, Pekalongan, Town,

community participation, socialization, awareness.

\begin{abstract}
MDA-LF is part of a global programme to eliminate lymphatic filariasis by less than $1 \%$ amongst the population, launched by World Health Organization (WHO) in 2000. This study aimed to find out the magnitude of coverage, the operational issues related to the process of drug distribution and as well as the success factors of MDA-LF LF.

Methods: This study used mixed method, interviewed 26 respondents and collected secondary data from Pekalongan Town Health Office.

Results: The coverage rate of MDA-LF LF in Pekalongan Town was $93 \%$ but the LF rate was still stand at $>1 \%$. There was no hindrance with the MDA-LF distribution, however, many people did not want to consume the MDA-LF drug package.
\end{abstract}

Copy Right, IJAR, 2019,. All rights reserved.

\section{Introduction:-}

Lymphatic filariasis (LF), commonly known as elephantiasis, is a neglected tropical disease. Infection occurs when filarial parasites are transmitted to humans through mosquitoes. Infection is usually acquired in childhood causing hidden damage to the lymphatic system. ${ }^{123}$ Evaluation is a process of a survey of a certain program to investigate the success of that program and place a hand on the limitations that led to failure of the programme. ${ }^{4}$ Mass Drug Administration (MDA-LF) is part of global programme to eliminate lymphatic filariasis, launched by world health organization in 2000. Basically MDA-LF is to prevent the spread of infection among population by cutting the chain of its transmission. ${ }^{5}$

In Indonesia, in 2009, it was estimated that there are more than 125 million at risk of LF living in 337 endemic provinces, however, 11,914 people in a chronic case have been reported. ${ }^{6}$ The rate of LF in Pekalongan Town varies from 1\%-39\% and almost all islands are endemic. In 2002, the Minister of Health declared the Indonesian participation on lymphatic filariasis elimination program based on World Health Organization (WHO) guideline in Banyuasin, South Sumatera. ${ }^{7}$ In order to accelerate the lymphatic filariasis elimination program in Indonesia, a strategic goal has been established by $\mathrm{MOH}$ republic of Indonesia for 5 rounds of MDA-LF to ensure the availability of the drug, MDA-LF implementation and to improve monitoring the MDA-LF programme through improving the advocating and the role of head of health district Office. With this new strategic plan, the lymphatic filariasis elimination program is able to cover all the endemic areas before the year $2020 .^{6}$ The coverage plays a crucial role of succeeding of the program, the coverage defined as the number of people have received the drug. In case of Pekalongan Town (Pekalongan is a Town located in Indonesia, Central Java with a population of 261,473), Based on secondary data obtained from Manager of Pekalongan Town Health Office, filariasis case in Pekalongan

Corresponding Author:-Ali Jarghon.

Address:-Faculty of Public Health, University of Diponegoro, Tembalang, Indonesia. 
Town was first found in 2002 in Kauman and Tegalrejo urban village in chronic condition (left leg swelling), and in 2010 from the blood samples that had taken from the people reported that filariasis rate $>1 \%$ which means that the area includes filariasis endemic, Mass Drug Administration (MDA-LF) has been implemented in Pekalongan Town for 7 years from 2011 to now. ${ }^{8}$

In Pekalongan Town there are 14 primary health centre providing the health care to a total of population 261,473 . According to the result of MDA-LF program of 2017, the total population who take the medicine was 223,733 and 15342 did not take the medicine.

\section{Material and Methods:-}

The study was conducted in the districts of Jenggot and Kertoharjo in Pekalongan Town, central Java, Indonesia. Which are known for endemiTown of LF. The study was undertaken during October -November 2018 and involved embedded mixed method. Qualitative data were collected through in-depth interview with Health Workers members $(\mathrm{n}=5)$ and with local people $(\mathrm{n}=20)$. The technique of data collection was done in triangulation, and data analysis was inductive. Quantitative data collected from the district health office of Pekalongan Town

\section{Results:-}

\section{Overview of MDA-LF LF Program in Pekalongan Town}

MDA-LF is a part of a global programme to eliminate Lymphatic Filariasis, launched by WHO in 2000. Basically, MDA-LF prevents the spread of infection amongst the population by interrupting the vector transmission. Based on secondary data obtained from the Manager of Pekalongan Town Health Office, LF case in Pekalongan Town was first found in 2002 in Kauman and Tegalrejo urban village in chronic condition (left leg swelling). In 2010, from the blood samples that had taken from the people reported that Filariasis rate was $>1 \%$ which means that the area includes Filariasis endemic, MDA-LF has been implemented in Pekalongan Town for 5 years from 2011 to 2015. The magnitude of MDA-LF LF in Pekalongan Town as shown in following figure.

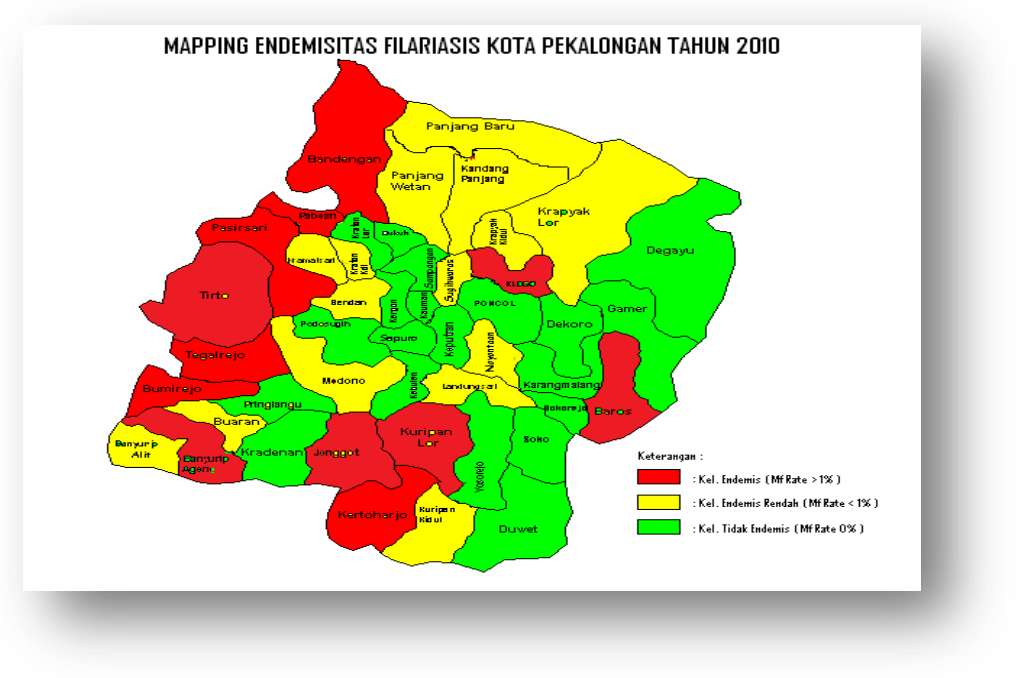

\section{Magnitude of Coverage}

Coverage is the total number of people received the drug. Based on data obtained from Health district office of Pekalongan Town, it shows that the rate of coverage is about $93 \%$. The table below showed a total number of population and the number of people who received the drug.

Table 1:-Magnitude of Coverage

\begin{tabular}{|c|r|r|r|}
\hline Sub-district & No. of Population & No. of People received the drug & Percentage \% \\
\hline North & 68.236 & 64.225 & $94 \%$ \\
\hline South & 58.229 & 55.809 & $95 \%$ \\
\hline West & 79.010 & 73.854 & $93 \%$ \\
\hline East & 67.073 & 61.608 & $91 \%$ \\
\hline Total & 272.514 & 255.469 & $93 \%$ \\
\hline
\end{tabular}


Source: secondary data

The result of the interviews that have been done on 20 respondents, showed that 18 out of 20 respondents have received the MDA-LF package.

\section{Drugs supply and Administration of LF}

The MDA-LF drug package delivered from the ministry of health to endemic provinces in Indonesia. The respected LF endemic provinces distributed the MDA-LF packages to the endemic areas, such as Pekalongan Town. Stored them in its pharmacy warehouse and distributed to its community health centres.

During the distribution in the past two years, drug demand data began at the provincial level. The office made supplies based on requests from the Primary Health Centre in accordance with their needs and targets. Then the Primary Health Centre took the drugs from the pharmacy warehouse in the health department and then they packed according to the target. The drug packages based on their ages:

1. Package 1 , for $2-5$ years

2. Package 2, for 6-14 years

3. Package 3 , for $>14$ years

In the Primary Health Centre, the medicine has been packaged according to the packet, then handed over to each sub-district through health volunteers. The health volunteers distributed the medicine to the community in several ways such as:

1. Through the community, the Primary Health Centre invited people to drink together.

2. Houses to the house carried out by health volunteers and supervised by health staff.

3. Schools, the Primary Health Centre invited students to drink together.

It has been revealed by the head of health district office of Pekalongan Town that the most effective methods that lead to high perectage of compliace are the drinking together through the community like religious commuitny and through schools. The house to house method was the lowest effective way because in this method the health volunteer distribute the drug to head of the family and later it depend on the family to share the drugs with other family members or just neglect it and thow the drug away. The figure below showed the process of drug distribution briefly.

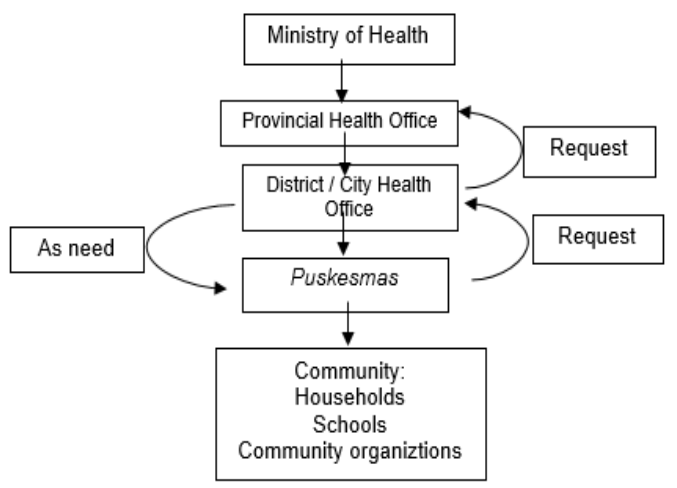

The health officers informed that the drug supply from the Central Java Provincial Health Office was running smoothly. Subsequently, the drug distribution to the sub-district health office, and to the community also has no hindrance. As shown in the following quotation.

"tidak ada masalah terkait dengan penawaran dan permintaan untuk proses pemberian obat" "there is no problem related to the supply and demand for drug administration process"

\section{Health Staff Availability}

The diversity of methods is required to achieve a good supply of the drug through the process of drug administration. The need is to keep the effectiveness of the drug distribution strategies that are adapted to its local needs. Worldwide a high rate of coverage about $90 \%$ is required for stopping transmission and elimination of the disease from the community. ${ }^{9}$ 
The primary health centre staff supported the health volunteer during the drugs' delivery to the people. In Pekalongan Town, there are 14 health centres. The program is supervised by the person in charge under the eradication of Infectious diseases officer (P2M). The health staffs were adequate and always suffice in assisting the health volunteers during the distribution process. On the other hand, the head of the primary centre stated that the health staffs were inadequate and lack of confidence during the distribution process. The quote of the in-depth interview as follow:

"staf/tenaga kesehatan cukup memadai dan mampu mendukung kader kesehatan dalam melakukan distribusi obat"

"the health staff are sufficient and supporting health volunteer through distribution of the drug"

The health volunteers played an important role in the distribution process of LF drugs, there were 73 Health volunteers in one primary health centre. They were in charge of distributing the drugs to 3,500 families, with a total of 13,500 family members.

To enhance the quality of Health volunteers, they were given communication training skills by the primary health centres to persuade the community on taking LF drugs. However, there were some health volunteers dropped out after completing the training. As shown in qoutation

"program pengembangan staf telah dilakukan bagi kader kesehatan sekali dalam sebulan"

"staff development program have been conducted for the Health volunteers once in a month"

A regular training were conducted once in a month for the Health volunteers to improve their skills and confidence because there are some health volunteers were inconfidence during the drug distribution process according to the head of primary health centre.

\section{Distribution Budget}

Funds are costs that needed to support the MDA-LF program. To achieve health targets it must be supported by sufficient funds and is a factor that significantly influences the quality of community health. The operasional definition of budget for this study was the money used during the drug distribution process. There are three sources of the budget such as:

1. Regional Budget and Expenditure (RBE), a.k.a APBD province;

2. RBE, a.k.a APBD Pekalongan Town; and

3. Health Operational Assistance (HOA), a.k.a BOK.

The lack of funds of any MDA-LF could lead to stop the program. According to program coordinator there was no problem related to funds for the distribution process. The quote of the in-depth interview was as follow

"tidak ada masalah terkait pendanaan selama distribusi obat"

"there is no issue related to funds during the drug distribution"

“...beberapa orang menolak untuk meminum obat dengan air saja dan mereka meminta pisang untuk memudahkannya, tidak ada alokasi anggaran untuk permintaan ini"

"some people refused to take the drug with water and they ask for banana, there is no budget allocation for this request"

There is a compensation fund for the health volunteers for every activity they did, the amount of its compensation depends on the type of activity. Usually a volunteer received Rp 35.000 for every activity, meanwhile, the staff could get Rp 40.000. The quote of the in-depth interview as follow

"relawan kesehatan dan staf kesehatan mendapatkan kompensasi untuk setiap kegiatan, masing-masing dari mereka adalah Rp 35.000 dan Rp 40.000"

" health volunteer and health staff get compensation for every activity, IDR 35,000 and Rp 40,000 respectively"

According to health volunteer, some people refused to take the drug with water only because they found difficulties to swallow it. Therefore, some of them requested for the banana to help them taking the drug. The cost in providing banana is not included on funds of LF drug distribution. The quote of the in-depth interview as follow:

"kami sering menemui banyak warga yang meminta pisang untuk membantu menelan obat dan kami tidak memiliki anggaran tambahan untuk menyediakan permintaan tersebut secara berkala"

"we often encountered many citizens who requested banana to help in swallowing the drug and we had no extra budget to provide such request periodically" 


\section{Area}

Both urban and rural area could affect the rate of the drug distribution which can lead to the low coverage percentage of the MDA-LF LF program. Even though Pekalongan Town is known as a Town with a lot of floods (rob), it did not affect both the distribution process and the coverage rate. According to main informants, Health volunteer can reach any place or house without any issue. The quote of the in-depth interview as follow:

"wilayah (perkotaan / pedesaan) tidak mempengaruhi cakupan/"

"area (urban / rural) has not affected the coverage".

\section{Discussion:-}

The first research objective investigated the magnitude regarding the coverage of MDA-LF LF amongst the residents of Pekalongan Town. A number of conclusions can be drawn from the results presented in chapter four and which pertains to the first research objective.

The in-depth interviews revealed that the coverage rate was about 93\%, which is quite high. However, Based on interviews that have been done on 20 respondents of Pekalongan residents 18 out of 20 have received the drug. In addition, based on other studies that have been done, the coverage rate was also high, coverage survey showed that $85 \% \%$ of people received drugs (coverage) in Gujarat, India. ${ }^{10}$

Drug supply and distribution process were one of the obstacles that could impact the MDA-LF program. Babu stated that the delay in supplies as well as processes to undertake MDA-LF in some places influenced the coverage and compliance. ${ }^{10}$ However, Respondents during the in-depth interviews revealed that the drug supply and process of distribution were run smoothly and impacted neither coverage nor compliance in Pekalongan Town.

The availability of Health staffs has its impact on any MDA-LF programme, in Burdwan District, India, the coverage was $48.76 \%$ due to the lack of the health staff availability and health volunteers. ${ }^{911}$ on the other hand, MDA-LF LF program in Pekalongan has scored a good rate of coverage during the 7 rounds of the program which means that MDA-LF LF did not have any issue regarding the availability of Health staffs and health volunteers.

MDA-LF for LF elimination is comparatively inexpensive in relation to most other public health programs. Governments and communities make the predominant financial contributions to actual MDA-LF implementation, not counting the cost of the drugs themselves. The usage health volunteers have its impact on the program, also it has been reported that the cost for the first round is higher than second or following rounds. ${ }^{12}$

One of this study findings is that the budget for distribution has its impact on the MDA-LF LF filariasis, some of Pekalongan residents refused taking the drug with water and asked for a banana to help them swallowing the drug, hence there is no a special budget for that. Which cause additional expenditure if the government will provide a banana for increasing the compliance rates.

Distributing the drug to urban regions is considered as a challenge amongst many countries delivering the MDA-LF LF. In India, it has been reported that drug delivery to urban areas was a special challenge, in Pekalongan, the health staffs and health volunteers stated that they can deliver the drug to all population wither in urban or rural areas with no obstacles. 13

\section{Aknowledgements:-}

I am highly thankful to Hanifa M. Denny, SKM, MPH, Ph.D, Dra. Chriswardani Suryawati, M.Kes., and Health district office of pekalongan town for their help and support at every step in carrying out this study.

\section{Ethical Approval}

The etical approval No: 243/EA/KEPK-FKM/2018 issued by diopnegoro university for the period of time November, 27st 2018 until November, 27st 2019.

\section{Bibliography:-}

1. Erdiansyah Adhami, Devisda Shay A, Bagas W.U., Febri Z F, Totalenesya R S, Wilsa Patricia, Nita Alanti, Yunita DewiAnggraeni, Winaspita Aulia Putri, Ra Bintang P, Madha QoyuledyT, Prisma Diandari, Yudha Nurdian. A Neglected Tropical Disease: Filariasis Caused by BrugiaMalayi Infections. 2018

2. WHO. Fact Sheet about Filariasis [Internet]. 2017. Available from: 
http://www.who.int/mediacentre/factsheets/fs102/en/

3. Indra Wijaya, winfrey pangestu. Giant Scrotal Hydrocele and Bilateral Leg Lymphedema as clinical Manifestation of Chronic Lymphatic Filariasis. The indonesian journal of internal medicine. 2016;48:239-241

4. U.S. Department of Health and Human Services. Centers for Disease Control and Prevention. Office of the Director, Office of Strategy and Innovation. Introduction to program evaluation for public health programs: A self-study guide. Atlanta, GA: Centers for Disease Control and Prevention, 2011.

5. Paul E Simonsen, Stephen M Magesa, Yahya A Derua, Erling M Pedersen. Lymphatic filariasis control in Tanga Region,Tanzania: status after eight rounds of mass drugadministration. Parasites \& vectors. 2014; (7).

6. Taniawati Supali. Summary of the current situation of filariasis in Indonesia. 2015; (3).

7. Supali, Ismid, Rückert, Fischer P. Treatment of Brugia timori and Wuchereria bancrofti infections in Indonesia using DEC or a combination of DEC and albendazole: adverse reactions and short-term effects on microfilariae. Trop Med Int Heal. 2002;7(10):894-901.

8. S. Budyanti. current status of Lymphatic filariasis in pekalongan. 2018; (5).

9. Roy RN, Sarkar AP, Misra R, Chakroborty A, Mondal TK BK. Coverage and awareness of and compliance with mass drug administration for elimination of lymphatic filariasis in Burdwan District, West Bengal, India. 2013;31:171-177.

10. B. V. Babu S kar. Coverage, compliance and some operational issues of mass drug administration during the programme to eliminate lymphatic filariasis in Orissa, India. Trop Med Int Heal. 2005;

11. Mirani V, Channa T Yahathugoda, Darshana Wickramasinghe, Kithsiri N Gunawardena, Rohan A Dharmadasa, Kanchana K Vidanapathirana SHW and WAS. Social mobilisation, drug coverage and compliance and adverse reactions in a Mass Drug Administration (MDA-LF) Programme for the Elimination of Lymphatic Filariasis in Sri Lanka. Filaria J. 2007;6.

12. Goldman AS, Guisinger VH, Aikins M, Amarillo MLE, Belizario VY, Garshong B et al. National Mass Drug Administration Costs for Lymphatic Filariasis Elimination. PLos Negl Trop Dis. 2007;1(1).

13. Agrawal S. Lymphatic Filariasis in India: Problems, Challenges and New Initiatives. ScienceDirect. 2006;62(4):359-62. 